\title{
GENEALOGI WACANA PADA PESAN AGITATIF PIDATO PRABOWO SUBIYANTO TENTANG NKRI BUBAR TAHUN 2030
}

\author{
Genealogy Discourse at The Agitative Message of Prabowo Subianto \\ Speech about Disperse Nation in 2030
}

\author{
Cosmas Gatot Haryono \\ Program Studi Ilmu Komunikasi, Universitas Bunda Mulia \\ Diterima 30 Januari 2019/ Disetujui 29 Maret 2019
}

\begin{abstract}
The 2019 presidential election (Pilpres) is a very hot political battle compared to the 2014 election. The temperature of national politics has begun to heat up starting several months before the official campaign period set by the KPU. The "open battle" between the Jowoki camp and Prabowo's camp grew stronger through criticism, criticism, and even physical insult to Jokowi who was the incumbent president. One interesting issue of the various polemics that adorn the world of national politics ahead of the 2019 presidential election is the issue of the dissolution of NKRI in 2030. Prabowo states that in 2030 Indonesia is predicted to disband because of the behavior of national political elites who are far from caring for the small people. Apart from weak references, the issue of the dissolution of the NKRI has been a discourse in our national politics in the past few weeks. In this case, Prabowo has succeeded in constructing subjective reality in the social reality of society for the benefit of himself. Through the power he had, Prabowo instilled an understanding of pessimism in the minds of the public that the state could fail and that the existing government also had the opportunity to fail, it needed to be replaced immediately. In the context of discourse fighting, even though it failed substantially, the speech was quite deceptive and horrendous. Despite experiencing an anti-climax, actually what was revealed by Prabowo was actually enough to help the community to identify some concerns or fears that the interests of many people (Indonesia) would be ruled out by the government. This research is a qualitative research with Faucoult's genealogy discourse method.
\end{abstract}

Keywords; Political Communication, Pessimism, Agitation, Genealogy Discourse

\section{ABSTRAK}

Pemilihan presiden (Pilpres) 2019 merupakan pertarungan politik yang sangat panas dibandingkan pemilu 2014. Suhu politik nasional mulai panas sudah dimulai sejak beberapa bulan menjelang masa kampanye resmi yang ditetapkan KPU. "Pertarungan terbuka" antara kubu Jowoki dan kubu Prabowo kian kencang melalui kritikan, kecaman, bahkan hinaan secara fisik terhadap Jokowi yang adalah presiden petahana. Salah satu isu yang menarik dari berbagai polemik yang menghiasi dunia politik nasional menjelang pilpres 2019 ini adalah isu bubarnya NKRI di tahun 2030. Prabowo menyatakan bahwa tahun 2030 Indonesia diprediksikan akan bubar karena perilaku para elit politik nasional yang jauh dari kepedulian terhadap rakyat kecil. Lepas dari referensi yang lemah, isu bubarnya NKRI telah menjadi wacana dalam politik nasional kita beberapa minggu terakhir. Dalam hal ini, Prabowo telah berhasil mengkonstrukikan realitas subyektif dalam realitas sosial masyarakat untuk kepentingan dirinya. Melalui power yang dimiliknya, Prabowo menanamkan pemahaman pesimisme dalam benak masyarakat bahwa negara bisa saja gagal dan pemerintahan yang ada sekarang pun berpeluang juga untuk gagal, maka perlu diganti segera. Dalam konteks pertarungan wacana, meskipun gagal secara substansi, pidato tersebut cukup mengecoh dan menghebohkan. Meskipun mengalami anti klimaks, sebenarnya apa yang diungkap Prabowo sebetulnya cukup membantu masyarakat untuk mengidentifikasi tentang adanya beberapa kekhawatiran atau ketakutan bahwa kepentingan masyarakat banyak (Indonesia) akan dikesampingkan oleh pemerintah. Penelitian ini merupakan penelitian kualitatif dengan metode genealogi wacana Faucoult.

Kata Kunci; Komunikasi Politik, Pesimisme, Agitasi, Genealogi Wacana

\footnotetext{
*Korespondensi Penulis:

E-mail: cgharyono@gmail.com
} 


\section{PENDAHULUAN}

Menjelang pemilihan presiden (Pilpres) 2019, suhu politik nasional mulai panas. Di periode awal tahun 2018 ini, "pertarungan terbuka" antara kubu pemerintah dan oposisi mulai dapat dirasakan. Kritikan, kecaman, bahkan hinaan secara fisik terhadap presiden berkuasa (Jokowi) mulai marak dilakukan oleh beberapa pihak di kubu oposisi. Yang memprihatinkan, kritikan dan serangan-serangan yang dilakukan kubu oposisi dilakukan lebih banyak pada persoalan person di pemerintahan bukan pada kebijakannnya. Kalaupun ada kritik terhadap kebijakan yang diambil pemerintah, sering kali tidak didasarkan pada data yang memadai dan cenderung hanya berkutat pada isu-isu lama yang direporoduksi ulang, seperti isu PKI, anti islam, hutang luar negeri, neolib, dan isu-isu yang berkaitan dengan keadaan fisik presiden Jokowi.

Tidak kalah garang, biasanya kubu pemerintah melakukan serangan balik terhadap para pengkritiknya. Tidak tangungtanggung, presiden sendiri sering kali menyerang balik para pengkritik yang tidak menyertakan data dalam mengkritik. Dengan dalih tidak anti kritik, mereka menuntut para oposan untuk tidak asal mengkritik, melainkan didasarkan pada data dan penghitungan yang rasional. Maka polemic tentang isu-isu tertentu biasanya selama berhari-hari bahkan berminggu-minggu menghiasi media massa nasional.

Kondisi ini menjadikan kubu oposisi justru tidak banyak mendapat respon positif di mata masyarakat. Sosok Jokowi sebagai incumbent justru semakin dikokohkan popularitasnya. Hal ini terlihat dari survey beberapa lembaga survey nasional yang masih menempatkan Jokowi sebagai capres terpopuler. Lembaga Populi Center misalnya, menempatkan Jokowi kokoh di peringkat pertama, yaitu mencapai 97,6 persen disusul Jusuf Kalla sebesar 94,1 persen, Megawati 91 persen Probowo 87,9 persen dan Anis Baswedan sebesar 75 persen www.beritasatu.com/politik/48094populicenter-popularitas-jikow-tidak- terkalahkan.html). Dari sisi elektabilitasnya, Survey kompas juga menempatkan Jokowi di puncak, jauh meninggalkan tokoh nasional lainnya. Hal itu terlihat dari survey terakhir Harian Kompas yang dipublikasikan pada Senin (29/5 2017) yang menunjukkan 41,6 persen responden menyatakan jika pemilu dilakukan saat ini akan memilih Jokowi. Adapun Prabowo yang selama ini di tempatkan sebagai rival politik Jokowi hanya dipilih 22,1 persen responden.

Salah satu isu yang menarik dari berbagai polemic yang menghiasi dunia politik nasional menjelang pilpres 2019 ini adalah isu bubarnya NKRI di tahun 2030. Isu ini dihembuskan oleh tokoh sentral oposisi, Prabowo Subianto dalam sebuah acara bedah buku berjudul "Nasionalisme Sosialisme dan Pragmatisme Pemikiran Ekonomi Politik Soemitro Djojohadikusumo" di kampus Fakultas Ekonomi dan Bisnis di Universitas Indonesia, 18 September 2017, yang di publish dalam account Facebook resmi partai Gerindra. Dalam pidatonya, Prabowo menyatakan bahwa tahun 2030 Indonesia diprediksikan akan bubar karena perilaku para elit politik nasional yang jauh dari kepedulian terhadap rakyat kecil. Para politisi terlalu sibuk dengan kepentingan diri mereka dan kelompoknya. Terlalu serakah dan justru menjadi "maling" yang merusak bangsa dan merugikan rakyat. Segera saja cuplikan pidato itu menjadi viral dan mengundang pro dan kontra dari berbagai politisi, pengamat politik, akademisi dan pelaku dunia maya.

Dari pihak istana juga tidak kalah berkomentar dan mempertanyakan pidato Prabowo tersebut. Melalui Juru Bicara Kepresidenan, Johan Budi, Istana mempertanyakan dasar dari pernyataan Prabowo bahwa Indonesia akan bubar tahun 2030. Menurut Johan, pemerintahan JokowiJK saat ini justru ingin menjadikan Indonesia negara maju. Pemerintah juga mencanangkan program Indonesia Emas pada tahun 2045 sehingga tidak mungkin sebelum itu Indonesia Bubar (www.makasar.tribunnews.com/lengkapinilah-isi-pidato-Prabowo-subianto-soalIndonesia-Bubar-2030.html). 


\section{METODE PENELITIAN}

Pidato politik seperti itu sebenarnya wajar-wajar saja karena sebagai partai oposisi sudah menjadi "marwah" nya untuk mengkritisi kebijakan dan perilaku pemerintah yang negative. Tetapi menjadi menarik ketika diketahui bahwa referensi yang digunakan Prabowo ternyata dari sebuah tulisan fiksi, yaitu novel Ghost Fleet yang bercerita tentang perang proxy antara negara America dan China di masa mendatang. Sebagai tokoh sentral di kubu oposisi, apapun yang dibicarakan Prabowo menjadi menarik dan akan selalu dikutip oleh media massa nasional. Maka fakta bahwa Prabowo menggunakan referensi dari sebuah novel fiksi ketika mengatakan NKRI akan bubar di tahun 2030, juga menjadi viral.

Dalam dunia politik, apa yang dikomunikasikan oleh para tokoh politik menjadi sangat penting dan ditunggu oleh khalayak ramai. Apapun yang diungkapkan atau diwacanakan politisi melalui komunikasi politik yang dilakukan akan menjadi sebuah wacana besar yang bisa saja mempengaruhi cara pandang dan cara bertindak seseorang. Sebagai pemimpin partai terbesar ke tiga di Indonesia, pidato yang diucapkan oleh Prabowo tentang bubarnya NKRI di tahun 2030 pasti bukan tanpa tujuan. Sebagai tokoh sentral oposisi, Prabowo berkepentingan dengan isu tersebut.

Lepas dari referensi yang lemah, isu bubarnya NKRI telah menjadi wacana dalam politik nasional kita beberapa minggu terakhir. Dalam hal ini, Prabowo telah berhasil mengkonstruk realitas subyektif dalam realitas sosial masyarakat untuk kepentingan dirinya. Melalui power yang dimiliknya, Prabowo menanamkan pemahaman pesimisme dalam benak masyarakat bahwa negara bisa saja gagal dan pemerintahan yang ada sekarang pun berpeluang juga untuk gagal, maka perlu diganti segera.

Peneliti tertarik untuk meneliti cuplikan pidato Prabowo Subianto yang dipublish di laman facebook resmi partai Gerindra tersebut dengan menggunakan analisis genealogi wacana Foucoult. Peneliti ingin melihat bagaimana kekuasaan, pengetahuan dan wacana saling kait-mengkait dalam pidato tersebut.

\section{Pidato atau Retorika Politik}

Pidato atau retorika politik merupakan suatu seni dan teknik dalam berkomunikasi yang banyak diaplikasikan dalam kegiatan politik (Arifin, 2011:126). Retorika sendiri berasal dari bahasa Yunani, Rhetorica, yang artinya seni berbicara. Di awal penggunannya retorika hanya digunakan untuk komunikasi interpersonal yang sifatnya dialogis. Namun dalam perkembangannya, retorika berkembang menjadi teknik dan seni untuk mempengaruhi orang lain yang jumlanya tidak lagi satu orang, melainkan banyak atau khalayak luas.

Sebagai seni berbicara, retorika bisa dicapai dengan mengandalkan bakat alam dan ketrampilan secara teknis (Hendrikus, 1991). Retorika juga merupakan seni menyusun argumentasi dan pembuatan naskah pidato karena retorika berkaitan dengan kegiatan persuasi. Sedangkan sebagai ilmu pengetahuan, retorika akan bisa dipahami dan dikuasai melalui pendidikan. Retorika kemudian diperluas pemahamannya sebagai segala cara manusia dalam menggunakan symbol untuk mempengaruhi lingkungan sekitarnya (Littlejohn, 2009: 73)

Plato memperkenalkan model retorika yang dinamakan dialectical rhetoric, yaitu retorika yang mengutamakan kebenaran sebagai fitrah manusia (Arifin, 2011: 128). Menurut plato, retorika merupakan suatu kemampuan mempengaruhi dan mengarahkan manusia secara positif kearah kebenaran. Seorang orator atau komunikator, dalam mengucapkan kata atau kalimat, baik secara implisit maupun eksplisit harus senantiasa berpedoman pada dasar-dasar yang didalamnya terdapat kebenaran dan kebajikan.

Seorang orator, selain harus memiliki pengetahuan mengenai kejiwaan manusia, ia juga harus memiliki kesadaran mendalam mengenai kebenaran, terutama aspek kebenaran suatu permasalahan yang dibicarakannya. Oleh karena itu, orator harus senantiasa terikat dan bertanggungjawab terhadap kejujuran dan perikebajikan.

Menurut Aristoteles, terdapat tiga jenis retorika, yaitu retorika deliberative, retorika forensic dan retorika demonstrative. Retorika deliberative dirancang untuk mempengaruhi khalayak dalam kebijakan pemerintah. Pembicaraaan difokuskan pada 
keuntungan dan kerugian jika sebuah kebijakan diputuskan dan dilaksanakan. Retorika forensic merupakan retorika yang berkaitan dengan pengadilan, dengan focus pembicaraan pada masa lampau yang berkaitan dengan keputusan-keputusan pengadilan. Sedangkan retorika demonstrative adalah retorika yang mengembangkan wacana yang dapat memuji atau menghujat. Dalam komunikasi politik, umumnya retorika politik yang lazim digunakan adalah retorika demonstrative untuk mempengaruhi khalayak.

Jika dilihat dari ragam jenisnya, terdapat empat jenis retorika atau pidato, yaitu: 1) impromptu; 2) memoriter; 3) manuskrip; dan 4) ekstempore (Arifin, 2011: 130)

\section{Agitasi Politik}

Agitasi berasal dari kata dalam bahasa Latin, yaitu agitare yang berarti bergerak, menggerakkan. Menurut Herbert Blummer (1969) agitasi adalah beroperasi untuk membangkitkan rakyat kepada suatu gerakan terutama gerakan politik. Agitasi dilakukan dengan membuat kontradiksi di masyarakat dan menggerakkan khalayak untuk menentang kenyataan hidup yang dialaminya selama ini (penuh ketidakpastian dan penderitaan) dengan tujuan menimbulkan kegelisahan di kalangan massa. Dalam kondisi seperti itu, rakyat akan mudah digerakkan untuk mendukung gagasan baru atau ideologi baru dengan menciptakan keadaan baru.

Dalam masyarakat komunis, agitasi merupakan bagian penting dalam sistem politik mereka. Bersama dengan propaganda, agitasi menjadi faktor kunci keberlangsungan politik dalam negara-negara komunis. Sebaliknya di alam demokrasi (Amerika dan negara-negara barat) sangat anti dengan agitasi karena dianggap sebagai kegiatan tercela. Bagi mereka, agitasi berkonotasi negatif karena sifatnya yang menghasut, mengancam, menggelisahkan dan membangkitkan rasa tidak puas di kalangan masayarakat serta mendorong pemberontakan.

Agitasi berupaya agar khalayak bersedia memberikan pengorbanan yang besar demi tujuan yang langsung bersedia mengorbankan jiwa untuk mewujudkan sebuah cita-cita politik. Melalui agitasi, seorang pemimpin mempertahankan kegairahan pengikutnya untuk memperoleh kemenangan yang akan diikuti oleh usaha- usaha selanjutnya dalam serangkaian tujuan (Arifi, 2011:131)

\section{Analisis Genealogi Wacana Foucault}

Pemikiran Foucault tentang wacana atau discourse selalu dikaitkan dengan dua entitas penting lainnya, yaitu kekuasaan (power), pengetahuan dan wacana. Pertama, Kekuasaan tidak terkonsentrasi pada kelas tertentu, melainkan menyebar ke seluruh lapisan. Pengetahuan pada dasarnya merupakan idea atau pemikiran yang ada dalam diri manusia. Sementara wacana merupakan struktur linguistic atau penggunaan bahasa dalam konteks masyarakat. Tiga hal tersebut mendasari kajian Foucault dalam melihat fenomena atau realitas yang terjadi dalam suatu konteks masyarakat (Ida, 2014: 111).

Dalam kerangka pemikiran Foucault ini, kekuasaan (power) memegang peranan yang sangat menentukan. Kekuasaan akan menentukan dan mengkonstruk adanya realitas-realitas yang diciptakan secara subyektif untuk kepentingan dan tujuan dari power domination atau kekuasaan yang mendominasi. Tekanan-tekanan, energy, material, pemikiran, kenikmatan dan sebagainya lebih banyak dikuasai oleh dominan ideology yang berlaku dalam konteks sosial masyarakat.

Kekuasaan sendiri dalam perspektif Foucault tidak dipandang sebagai milik yang bisa dikuasai dan digunakan oleh kelas tertentu untuk mendominasi dan menindas kelas yang lain seperti dikatakan Marx. Bukan pula kemampuan subyektif untuk mempengaruhi orang lain seperti pandangan Weber. Kuasa tidak sekedar terkonsentrasi di tangan penguasa struktur-struktur yang menononjol seperti perusahaan, negara dan organisasi agama. Melainkan kekuasaan itu menyebar, terpencar dan hadir di mana-mana seperti jaring yang menjerat kita semua. Kekuasaan "merasuki" seluruh bidang kehidupan masyarakat modern. Kekuasaan ada di semua lapisan, kecil dan besar, laki-laki dan perempuan, dalam keluarga, di sekolan dan sebagainya (Widyarsono, 1999: 11).

Kekuasaan menentukan proses-proses tubuh, pola tingkah, dan mendikte perilaku manusia terhadap realitas yang sebenarnya milik dari ideology dominan. Kekuasaan bekerja atau beroperasi dalam diri setiap orang pada level yang terus menerus dan proses 
yang tidak pernah diinterupsi (atau seolah benar) yang mendefinisikan tubuh manusia, mengatur cara manusia bertindak, mengatur gesture atau gerakan tubh, mendikte perilaku manusia dan sebagainya. Maka dalam analisis discourse, harus dilihat kekuatan-kekuatan atau power yang mengitari area discourse.

Dalam pembentukan subyektivitas yang dimiliki masing-masing individu, power memegang peranan yang sangat viatl. Kekuasaan ini, dengan energinya, dengan material yang dimililkinya, dengan interest atau tujuan yang diinginkannya telah mendikte cara-cara individu atau manusia lainnya untuk bertindak dan berperilaku dalam peranperannya di masyarakat, termasuk bahasa, ucapan, percakapan, dan tulisan atau teks yang dihasilkan (Ida, 2014: 112-113)

Kedua, pengetahuan. Menurut Faoucault, kekuasaan beroperasi secara positif dan produktif. Dalam praktek penggunaannya, kekuasaan selalu berkaitan dengan pengetahuan. Terkait dengan ini, penjelasannya sekaligus mengkritik pandangan para pemikir renessaince yang memisahkan antara kebenaran dan ideology, antara pengetahuan dan kekuasaan. Para pemikir renessaince menganggap kebenaran atau pengetahuan berada di luar relasi kuas, yang berada "di luar sana". Maka kebenaran dapat memeriksa dan mengatur cara kerja kekuasaan. Dengan kata lain, kebenaran atau pengetahuan dipercayai memiliki kekuatan untuk membebaskan manusia (fungsi emansipatoris) dari relasi kuasa yang menindas. Sebaliknya, Foucault menganggap justru kebenaran atau pengetahuan tidak terletak di luar, melainkan di dalam kuasa. Kebenenaran atau pengetahuan adalah relasi kuasa itu sendiri.

Argumen lain Foucault tentang kebenaran atau pengetahuan adalah keyakinannya bahwa dalam discourse, kebenaran atau pengetahuan harus dilihat dari tiga sisi sekaligus, yaitu: 1) dari siapa yang menyatakannya, 2) bahasa yang digunakan dan 3) bagaimana subyek menilai atau mendefinisikan kebenaran itu sendiri. Dari ketiga sisi itulah pengetahuan bisa diungkap asalnya dan menemukan konteks aslinya.

Produksi dan reproduksi pengetahuan dan kebenaran yang kemudian disebarkan kepada public tergantung pada bagaimana pengetahuan dan kebenaran itu disampaikan. Pengetahuan dan kebenaran pada akhirnya hanyalah milik kekuasaan dominan. Akhirnya kebenaran tergantung pada siapa yang menyampaikannya atau memproduksinya.

Maka diperlukan analisis terhadap grammar atau tata bahasa atau aturan pengunaan kata dan kalimat menjadi hal perlu dilakukan. Pertanyaan-pertanyan menarik yang perlu diungkapkan dalam pendekatan Foucault antara lain, bagaimana kebenaran itu dapat dikatakan? Bagaimana yang dimaksudan di sini adalah teknik-teknik apa saja yang digunakan untuk mendefinisikan kebenaran? Berdasarkan aturan-aturan yang mana? Dan dalam kondisi yang seperti apa? Apakah sesuatu mungkin dianalisis atau diperhitungkan sebagai kebenaran?Foucault menegaskan bahwa melalui analisis gramatikal inilah pengetahuan dan kebenaran itu terjadi atau terbentuk. Untuk mendapatkan kebenaran, maka seseorang diharapkan mencari atau mempertanyakan lebih jauh tentang hakikat atau darimana kebenaran itu sendiri diperoleh atau bersumber (Ida, 2014: 115).

Dalam diri setiap individu sendiri, menurut Foucault, terdapat sebuah mekanisme pokok pendisiplinan diri yang disertai dengan mekanisme "pemantauan" (pengawasan), penghukuman, normalisasi, dan pegujian peringkat (L'examen). Mekanisme L'examaen sendiri merupakan sebuah mekanisme yang sekaligus memantau, menentukan peringkat (rangking), tetapi juga melatih. Oleh karena itu, mekanisme L'examen bisa dikatakan sebagai prosedur komplet dari proyek pendisiplinan diri (Widyarsono, 1999: 13).

Mekanisme ini menjadi sebuah hal yang mendasar ada dalam diri individu dan biasa disebut sebagai hubungan 'panoptikon' dimana seluruh prosedur penaklukan menjadikan diri individu patuh dan bergunan mendapatkan realitasnya. Dalam panoptikon ini, individu terus menerus ditaklukkan, dipantau dan diketahui. Penaklukan total atas individu pada gilirannya memberikan pengetahuan menyeluruh atas diri individu itu sendiri.

Ketiga, wacana atau discourse. Foucault berfikir tentang discourse dalam kaitannya dengan kerangka pengetahuan atau bodies of knowledge.dalam hal ini, sesuatu yang bergerak dari hal-hal yang berkaitn dengan sistem kebahasaan (grammatical) dan mengarah pada konsep disiplin seperti ilmu pengethuan, kedokteran, spikiatri dan sebagainya; serta pada konsep-konsep tentang disiplin, institusi control sosial seperti 
sekolah, penjara, rumah sakit dan sebagainya (Ida, 2014: 116).

Selain persoalan produksi bahasa dan tata bahasa, discourse juga dimaknai sebagai konteks dimana bahasa itu digunakan dan aturan yang menaungi penggunan bahasa tersebut. Maka discourse yang terjadi dalam suatu realitas atau fenomena yang diamati peneliti tidak saja dipandang sebabagai sesuatu yang muncul dengan sendirinya. Melainkan institusi-institusi yang ada sebagai tempat beroperasinya discourse bahasa sehingga menjadi penting dan signifikan untuk dianalisis.

Dengan demikian, discourse bukanlah sebuah prosedur atau aturan main untuk menghasilkan consensus, melainkan praktik wacana itu sendiri secara actual mengenai satu hal (Poespowardojo, 2016: 235). Wacana bagi Foucault bukan menyatukan berbagai pandangan menjadi satu (semangat dasar filsafat) atau menyajikan perbedaan tentang berbagai hal (semangat dasar linguistic), melainkan menjelaskan bahwa kekuasaan itu menyebar, ada di mana-mana (systems of dispersion). Wacana tidak ditentukan oleh subyek, tetapi oleh obyek yang dibicarakan. Maka, apa yang ditemukan dalam wacana bukan sebuah konfigurasi yang dibuat oleh subyek, melainkan pola yang bersifat imanen pada apa yang dibicarakan (Foucault, 1972: 46). Peran obyek dalam praktik wacana memungkinkan tampilnya pemahaman subyek struktur obyektif yangmenampilkan makna bagi pemahaman subyek (Foucault, 1997: 94)

\section{Struktur Analisis Genealogi Wacana}

Seperti telah dibahas di bagian sebelumnya, wacana pada dasarnya merupakan sistem pengetahuan yang memberikan informasi tentang teknologi sosial dan teknologi memerintah yang merupakan bentuk kekuasaan dalam masyarakat modern. Foucault lebih tertarik melihat wacana sebagai aturan-aturan dan praktik-praktik yang menghasilkan masalahmasalah bermakna dan diatur sesuai dengan periode sejarah. Artinya, ada struktur pemaknaan yang menentukan pada suatu periode sejarah tertentu (Haryatmono, 2016: 66).

Setip praktek wacana pasti mempunyai hubungan dengan institusi-institusi sosial dalam masyarakat. Bahkan, antar satu wacana dengan wacana yang lainnya selalu mempunyai keterkaitn dan tidak saling lepas. Teks-teks baru selalu berhubungan teks-teks sebelumnya. Maka, dalam memahami analisis genealogi wacana Foucault, harus diperhatikan keterhubungan antar wacana dan konteks sosialnya.

Dalam melakukan analisis genealogi wacana Foucault (Ida, 2014: 119-123), ada beberapa materi analisis yang harus dilakukan, antara lain: analisis linguistic structural, analisis arsip, analysis archaeology of knowledge, dan analisis formasi diskursif. Pertama, Analisis linguistic structural adalah metode yang digunakan untuk melihat praktikpraktik discourse dalam masyarakat, dengan mengamati bahasa atau ucapan atau teks tertulis yang muncul atau digunakan dalam konteks institusi sosial tertentu. Sebagaimana diketahui, bahasa dibentuk oleh strukturstruktur gramatikal dari bahasa itu sendiri. Gramatikal atau tata bahasa akan menentukan kekuasaan (power) dan pengetahuan (knowledge). Dalam menggunakan bahasa, selalu ada penggunaan symbol yang merupakan hasil dari konvensi-konvensi budaya masyarakat.

Kedua, analisis terhadap arsip-arsip (archives), yaitu teks-teks massal yang dikoleksi pada periode waktu tertentu. Arsip juga bisa diartikan sebagai sekumpulan aturan yang pada suatu periode tertentu dan pada suatumasyarakt tertentu (Foucault, 1978: 1415). Ketiga, Archaelogy of knowledge (arkeologi pengetahuan) merupakan salah satu yang khas dari analisis discourse Foucault. Yang dimaksud archaeology of knowledge adalah seperangkat metodologi yang dapat digunakan untuk mempelajari bagaimana retorika atau pernyataan-pernyataan yang disampaikan dapat dipelajari dan dipahami dalam kaitannya dengan kekuasaan (power) dan pengetahuan (knowledge).

Foucoult melihat bahwa semua bahanbahan (manifest) discourse didasarkan secara tersembunyi pada apa yang diucapkan (already said), yaitu tidak hanya frasa yang telah diucapkan atau teks yang telah tertulis, tetapi tidak pernah diucapkan (never said), yang berkaitan (incorporated) dengan discourse, suara yang sunyi seperti nafas, tulisan yang hanya merupakan bagian dari pendandanya sendiri. Dengan kata lain, archaelogy of knowledge menyediakan seperangkat metodologi bagi peneliti untuk melihat dan memahami discourse yang ada dengan melihat bahasa-bahasa yang tampak 
dan tidak tampak, ujaran-ujaran yang dikatakan dan ujaran-ujaran yang tersembunyi yang tidak pernah disampaikan, termasuk tulisan-tulisan yang bahkan tidak jelas dan tidak dapat dibaca sekalipun (Ida, 2014: 122).

Keempat, formasi diskursif (discursive formation) merupakan metode yang mendiakan perangkat analisis bagi peneliti untuk melihat danmemahami pernyataan (statement), kejadian atau peristiwa (event) dan discourse yang dihasilkan. Formasi diskursif bisa berupa discourse-discourse yang terbentuk dan beredar dalam masyarakat tentang suatu hal. Dalam formasi diskursif, discourse selalu dipahami terbentuk karena dipengaruhi oleh kekuasaan, ideology, dan pengetahuan tertentu.

\section{HASIL DAN PEMBAHASAN}

\section{Analisis Linguistic structural}

Pada bagian ini peneliti akan melihat bagaimana praktik-praktik discourse yang dikembangkan dengan mengamati bahasa atau ucapan atau teks tertulis yang muncul atau digunakan dalam konteks institusi sosial tertentu. Sebagaimana diketahui, bahasa dibentuk oleh struktur-struktur gramatikal dari bahasa itu sendiri. Gramatikal atau tata bahasa akan menentukan kekuasaan (power) dan pengetahuan (knowledge). Aspek gramatikal sendiri meliputi: (1) pengacuan (referensi), (2) penyulihan (subtitusi), (3) pelesapan (ellipsis), dan (4) perangkaian (konjungsi).

\section{Pengacuan (Referensi)}

Pengacuan atau referensi menjelaskan tentang adanya satuan lingual tertentu yang mengacu pada satuan lingual lain (atau suatu acuan) yang mendahului atau mengikutinya. Ada tiga jensi pengacuan: pengacuan persona, demonstratif, dan komparatif. (Sumarlam, 2008: 23-24).

\subsection{Pengacuan Persona}

Dalam pidato Prabowo ini, pengacuan persona berupa pengacuan persona pertama jamak dan tidak ditemukan pengacuan persona tunggal. Pengacuan persona pertama jamak menggunakan kata "kita" yang mengacu pada seluruh rakyat Indonesia, termasuk Prabowo dan orang-oang yang hadir di situ. Beberapa kalimat yang diucapkan Prabowo menggunakan pengacuan persona pertama jamak, yaitu kita sebanyak 9 (sembilan) kali. Prabowo tidak pernah menggunakan kata saya dalam pidato tersebut. Pengacuan persona "kita" mengacu pada keseluruhan warga negara atau bangsa Indonesia. Jadi Prabowo menekankan bahwa dirinya termasuk didalam keseluruhan warga bangsa tersebut.

Selain pengacuan persona pertama, Prabowo juga menggunakan pengacuan kedua jamak sebanyak 3 (tiga) kali dengan dua jenis kata yang berbeda, yaitu "saudara-saudara" dan "bung". Keduanya merupakan bentuk kata sapaan. Kata "saudara-saudara" mengacu pada kata sapaan kepada orang lain yang diajak berbicara. Sedangkan kata "Bung" mengacu pada kata sapaan yang tidak biasa karena mengandung makna historis. Kata "bung" melekat pada era revolusi fisik / perjuangan atau minimal menggambarkan suasana revolusi yang sedang digelorakan. Dalam pidato tersebut, tidak ditemukan sama sekali pengacuan persona kedua tunggal.

Sementara bentuk pengacuan persona ketiga berupa persona ketiga jamak, yang pada penggunaan kata "mereka" dalam pidato tersebut sebanyak 2 (dua) kali. Kata "mereka" merujuk pada bangsa-bangsa lain di dunia yang lebih maju daripada Indonesia. Prabowo tidak menggunakan persona ketiga tunggal sama sekali. Hal ini bisa dipahami karena pidato Prabowo dilakukan di depan massa. 
Tabel 1. Pengacuan (Referensi) Persona

\begin{tabular}{|c|c|c|c|}
\hline Kalimat/ Frase & $\begin{array}{l}\text { Pengacuan } \\
\text { Persona } \\
\text { Pertama } \\
\text { Jamak }\end{array}$ & $\begin{array}{l}\text { Pengacuan } \\
\text { Kedua } \\
\text { Jamak }\end{array}$ & $\begin{array}{l}\text { Pengacuan } \\
\text { Ketiga } \\
\text { Jamak }\end{array}$ \\
\hline $\begin{array}{l}\text { Saudara-Saudara, } \\
\text { Kita masih upacara, kita masih menyanyikan } \\
\text { lagu kebangsaan, kita masih pakai lambang- } \\
\text { lambang negara, gambar-gambar pendiri bangsa } \\
\text { masih ada di sini, tetapi di negara lain mereka } \\
\text { sudah bikin kajian-kajian, di mana Republik } \\
\text { Indonesia sudah dinyatakan tidak ada lagi tahun } \\
\text { 2030. }\end{array}$ & Kita $(3 \mathrm{x})$ & $\begin{array}{c}\text { Saudara- } \\
\text { saudara }(1 \mathrm{x})\end{array}$ & $\begin{array}{c}\text { Mereka } \\
(1 \mathrm{x})\end{array}$ \\
\hline $\begin{array}{l}\text { Bung! } \\
\text { Mereka ramalkan kita ini bubar, elit kita ini } \\
\text { merasa bahwa } 80 \text { persen tanah seluruh negara } \\
\text { dikuasai } 1 \text { persen rakyat kita, nggak apa-apa. }\end{array}$ & Kita $(3 \mathrm{x})$ & Bung (1x) & $\begin{array}{l}\text { Mereka } \\
\quad(1 \mathrm{x})\end{array}$ \\
\hline $\begin{array}{l}\text { Bahwa sebagian besar kekayaan kita diambil ke } \\
\text { luar negeri tidak tinggal di Indonesia, tidak apa- } \\
\text { apa }\end{array}$ & Kita $(1 \mathrm{x})$ & & \\
\hline $\begin{array}{l}\text { Ini yang merusak bangsa kita, saudara-saudara } \\
\text { sekalian! }\end{array}$ & Kita $(1 \mathrm{x})$ & $\begin{array}{l}\text { Saudara- } \\
\text { saudara } \\
\text { sekalian } \\
(1 \mathrm{x})\end{array}$ & \\
\hline $\begin{array}{l}\text { Tidak enak kita bicara, tapi sudah tidak ada } \\
\text { waktu untuk kita pura-pura lagi. }\end{array}$ & Kita $(1 \mathrm{x})$ & & \\
\hline
\end{tabular}

\subsection{Pengacuan Demonstratif}

Terdapat dua jenis pengacuan demonstratif, yaitu pronomina demonstratif waktu (temporal) dan pronomina demonstratif tempat (lokasional). Pronomina demonstratif waktu mengacu pada waktu kini, lampau, akan datang, dan waktu netral. Dalam pidato Prabowo ini, terdapat dua pronomina demonstratif waktu kini dan akan datang. Waktu masa kini diwakilkan oleh penggunaan kata "masih" pada frase "Kita masih upacara, kita masih menyanyikan lagu kebangsaan, kita masih pakai lambang-lambang negara, gambar-gambar pendiri bangsa masih ada di sini”. Sedangkan pronomina demonstratif waktu masa akan datang tampak pada prediksi Prabowo tahun 2030.

Melalui pengacuan demonstratif waktu ini menunjukkan bahwa wacana kekinian akan menemukan kontradiksinya di masa yang akan datang. Prabowo mencoba membangun wacana yang kontras antara masa kini dan masa datang. Apa yang terjadi di masa depan di perkirakan akan sangat berkebalikan dengan yang terjadi saat ini.

Tabel 2. Pengacuan Demonstratif Waktu

\begin{tabular}{ll}
\multicolumn{1}{c}{ Kalimat / Frase } & \multicolumn{1}{c}{$\begin{array}{c}\text { Pronomina Demonstratif } \\
\text { Waktu }\end{array}$} \\
\hline Kita masih upacara, kita masih menyanyikan lagu kebangsaan, & Waktu kini dan Waktu akan \\
kita masih pakai lambang-lambang negara, gambar-gambar & datang \\
pendiri bangsa masih ada di sini, tetapi di negara lain mereka & \\
sudah bikin kajian-kajian, di mana Republik Indonesia sudah & \\
dinyatakan tidak ada lagi tahun 2030. & \\
\hline
\end{tabular}


Sedangkan pronominal demonstratif tempat (lokasi) tampak Prabowo melalui pidatonya membangun dua tempat yang berbeda, yaitu tempat yang dekat (di sini = Indonesia) dan tempat yang jauh dari ruang pembicara (di luar sana = negara-negara maju yang mempredikasi Indonesia akan bubar di tahun 2030). Dua lokasi yang berbeda ini menggambarkan dua lokasi yang berbeda dengan pandangan atau wacana yang berbeda.

\subsection{Pengacuan Komparatif}

Jenis pengacuan komparatif (perbandingan) pada dasarnya merupakan jenis aspek gramatikal yang mencoba membandingkan dua hal atau lebih yang mempunyai kemiripan atau kesamaan dari segi bentuk/wujud, sikap, watak, perilaku, dan sebagainya. Dalam pidato ini, Prabowo menggunakan pengacuan komparatif juga, yaitu membandingkan kepemilikan tanah di negara Indonesia dibandingkan dengan prosentase golongan masyarakat Indonesia. Ia menggambarkan mayoritas tanah di Indonesia yang digambarkannya dengan angka 80 persen dikuasai oleg sgelintir elit yang digambarkan dengan prosentase 1 persen dari keseluruhan rakyat Indoesia. Ini merupakan sebuah pembangunan wacana kontradiksi 1 persen menguasai 80 persen. Bahkan kemudian dipertegas dengan kalimat, "hampir semua asset dikuasai 1 persen".

\section{"Bung!}

Mereka ramalkan kita ini bubar, elit

kita ini merasa bahwa 80 persen

tanah seluruh negara dikuasai 1

persen rakyat kita, nggak apa-apa.

Bahwa hampir seluruh aset dikuasai 1

persen, nggak apa-apa".

\section{Penyulihan (Subtitusi)}

Subtitusi merupakan salah satu aspek dari gramatikal yang terlihat dari bagaimana penggantian satuan lingual tertentu dengan satuan lingual lain dengan tujuan untuk memperoleh unsur pembeda. Subtitusi sendiri terdiri dari: subtitusi nominal, verbal, frasa, dan klausal (Sumarlam, 2008: 28).

\subsection{Subtitusi Nominal}

Subtitusi nominal merupakan penggantian satuan lingual yang berkategori nominal. Dalam pidato Prabowo ini ditemukan beberapa subtitusi nominal, yaitu: elit kita, 80 persen tanah kita, 1 persen rakyat, hampir seluruh asset, dan sebagian besar kekayaan kita. Subtitusi nominal tersebut dapat dilihat pada data berikut.

Tabel 3. Substitusi Nominal

Kalimat/ Frase $\quad$ Substitusi Nominal

\begin{tabular}{ll}
\hline $\begin{array}{l}\text { Mereka ramalkan kita ini bubar, elit kita ini merasa bahwa 80 persen } \\
\text { tanah seluruh negara dikuasai 1 persen rakyat kita, nggak apa-apa. }\end{array}$ & $\bullet$ 80 persen tanah \\
\hline Bahwa hampir seluruh aset dikuasai 1 persen, nggak apa-apa. & $\begin{array}{l}\bullet \text { Hampir seluruh } \\
\text { asset } \\
\bullet\end{array}$ \\
$\begin{array}{ll}\text { Bahwa sebagian besar kekayaan kita diambil ke luar negeri tidak } \\
\text { tinggal di Indonesia, tidak apa-apa. }\end{array}$ & $\begin{array}{l}\bullet \text { Sebagian besar } \\
\text { kekayaan }\end{array}$ \\
\hline
\end{tabular}

\subsection{Substitusi Verbal dan Frasal}

Subtitusi verbal merupakan pemanfaatan sebuah lingual berkategogi verbal untuk mengganti satuan lingual lainnya dengan tujuan tertentu. Dalam pidato singkat Prabowo ini tidak terdapat kategori substitusi verbal yang digunakan. Sedangkan substitusi Frasal merupakan bagian dari aspek gramatikal yang dilakukan dengan penggantian satuan lingual tertentu yang berupa kata atau frasa dengan satuan lingual lain yang berupa frasa. Dalam pidato Prabowo ini juga tidak terdapat substitusi frasa. 


\subsection{Substitusi Klausal}

Subtitusi klausal merupakan penggantian satuan lingual tertentu yang berupa klausa atau kalimat dengan satuan lingual lain yang berupa kata atau frasa. Dalam pidato ini, Prabowo banyak menggunakan substitusi klausal. Setidaknya empat kalimat yang mengandung substitusi klausal, yaitu:

1)Bahwa hampir seluruh aset dikuasai 1 persen, nggak apa-apa.

2)Bahwa sebagian besar kekayaan kita diambil ke luar negeri tidak tinggal di Indonesia, tidak apa-apa.

3)Ini yang merusak bangsa kita, saudarasaudara sekalian!

4)Semakin pintar, semakin tinggi kedudukan, semakin curang! Semakin culas! Semakin maling!
Keempat kalimat yang digunakan Prabowo tersebut masing-masing mengandung substitusi yang mengacu pada klausa atau kalimat yang disebutkan sebelumnya, yaitu elit kita merasa tidak masalah ("ngga apaapa") dengan fakta-fakta yang diungkapkan Prabowo tersebut. Semua mengacu pada kondisi para elit kita yang dinilai prabowo tidak peduli dengan kondisi yang ada.

\section{Ellipsis}

Pelesapan (ellipsis) meruapakan salah satu aspek gramatikal yang berupa penghilangan atau pelesapan satuan lingual tertentu yang telah disebutkan sebelumnya. Dalam pidato Prabowo ini terdapat beberapa kali ellipsis yang dilakukan, antara lain:

\section{Tabel 4. Satuan Lingual Yang Mengalami Ellipsis}

\begin{tabular}{ll}
\hline \multicolumn{1}{c}{ Kalimat atau Frase } & \multicolumn{1}{c}{ Ellipsis } \\
\hline $\begin{array}{l}\text { Kita masih upacara, kita masih menyanyikan lagu kebangsaan, kita } \\
\text { masih pakai lambang-lambang negara, gambar-gambar pendiri } \\
\text { bangsa masih ada di sini, tetapi di negara lain mereka sudah bikin } \\
\text { kajian-kajian, di mana Republik Indonesia sudah dinyatakan tidak } \\
\text { ada lagi tahun 2030. }\end{array}$ & \\
& \\
\hline $\begin{array}{l}\text { Mereka ramalkan kita ini bubar, elit kita ini merasa bahwa } 80 \\
\text { persen tanah seluruh negara dikuasai 1 persen rakyat kita, nggak } \\
\text { apa-apa. }\end{array}$ & Subyek: Elit kita \\
\hline Bahwa hampir seluruh aset dikuasai 1 persen, nggak apa-apa. & Subyek kalimat: elit kita \\
\hline $\begin{array}{l}\text { Bahwa sebagian besar kekayaan kita diambil ke luar negeri tidak } \\
\text { tinggal di Indonesia, tidak apa-apa. }\end{array}$ & Subyek kalimat: elit kita \\
\hline $\begin{array}{l}\text { Semakin pintar, semakin tinggi kedudukan, semakin curang! } \\
\text { Semakin culas! Semakin maling! }\end{array}$ & Subyek kalimat: elit kita \\
\hline
\end{tabular}

Melalui ellipsis ini, sebenarnya Prabowo mau "menyerang" para tokoh bangsa ini tetapi dilakukan dengan tidak secara frontal. Metode ellipsis merupakan salah satu cara yang membuat pesan tidak secara tegas "menembak" siapa karena mengandung makna ganda dan mempersulit penafsiran. Tetapi bila dilihat dari rangkaian kalimat secara keseluruhan akan terlihat jelas bahwa yang "diserang" oleh Prabowo adalah elit politik atau para penguasa saat ini.

\section{Konjungsi}

Konjungsi merupakan salah satu aspek gramatikal yang melihat bagaimana menghubungkan unsur yang satu dengan unsur yang lain dalam wacana. Menurut Sumarlam (2008: 32-33) berdasarkan maknanya, perangkaian unsur dalam wacana dibedakan menjadi antara lain: sebab-akibat, pertentangan, kelebihan, perkecualian, konsesif, tujuan, penambahan, pilihan, harapan, urutan, perlawanan, waktu, syarat, dan cara.

Dari pidato Prabowo tersebut, dapat ditemukan bahwa perangkaian unsur dalam 
wacana dilakukan dengan pertentangan dan sebab akibat. Perangkaian pertentangan terlihat sejak kalimat pertama dimana Prabowo mencoba mempertentangkan apa yang orang Indonesia lakukan dengan ramalan orang asing terhadap Indonesia. Rangkaian pertentangan ini kemudian dipadu-padankan dengan rangkaian sebab akibat sehingga memperoleh alur cerita yang semakin "terasa" logis.

Tabel 5. Perangkaian Unsur-Unsur Wacana (Konjungsi)

\begin{tabular}{ll}
\hline \multicolumn{1}{c}{ Kalimat atau Frase } & Konjungsi \\
\hline Kita masih upacara, kita masih menyanyikan lagu kebangsaan, kita masih pakai & Pertentangan \\
lambang-lambang negara, gambar-gambar pendiri bangsa masih ada di sini, & \\
tetapi di negara lain mereka sudah bikin kajian-kajian, di mana Republik & \\
$\begin{array}{l}\text { Indonesia sudah dinyatakan tidak ada lagi tahun 2030. } \\
\text { Mereka ramalkan kita ini bubar, elit kita ini merasa bahwa 80 persen tanah } \\
\text { seluruh negara dikuasai 1 persen rakyat kita, nggak apa-apa. }\end{array}$ & Pertentangan \\
\hline Bahwa hampir seluruh aset dikuasai 1 persen, nggak apa-apa. & \\
Bahwa sebagian besar kekayaan kita diambil ke luar negeri tidak tinggal di & Pertentangan \\
$\begin{array}{l}\text { Indonesia, tidak apa-apa. } \\
\text { Ini yang merusak bangsa kita, saudara-saudara sekalian! }\end{array}$ & Petentangan \\
\end{tabular}

Semakin pintar, semakin tinggi kedudukan, semakin curang! Semakin culas!

Sebab-akibat Semakin maling!

Konjungsi yang dipilih Prabowo, secara garis besar sebenarnya sangat logis dan masuk akal. Permainan kalimat dengan model pertentangan menggambarkan bahwa Prabowo menguasai seluk-beluk masalah tersebut. Bagi sebagian kalangan terutama kalangan menengah ke bawah, model konjungsi pertentangan menjadi lebih mudah dipahami karena hanya ada dua nilai, yaitu: baik-buruk, hitam-putih. Siapa yang baik dan siapa yang buruk sangat mudah dipahami dalam penyataan yang disampaikan oleh Prabowo tersebut.

Kemudian pandangan tersebut dipertegas dengan mengungkap akibatnya apa bagi bangsa ini. Model penuturan sebab akibat ini semakin mempermudah masyarakat mengetahui makna pesan dari pidato Prabowo tersebut.

\section{Analisis Arsip}

Analisis terhadap arsip-arsip (archives), yaitu teks-teks massal yang dikoleksi pada periode waktu tertentu. Arsip juga bisa diartikan sebagai sekumpulan aturan yang pada suatu periode tertentu dan pada suatu masyarakat tertentu (Foucault, 1978: 1415). Penting untuk menekankan persoalan aturan atau kesepakatan penggunaan kata ataupun kalimat dalam sebuah periode waktu tertentu.
Dalam konteks pidato singkat Prabowo, terdapat beberapa kata atau kalimat yang bila dikaitkan dengan periode saat ini, mengandung pesan yang mendalam karena mereferensikan sesuatu. Misalnya pada kalimat pertama, Prabowo mengungkapkan bahwa saat ini kita yang masih melakukan upacara bendera, menyanyikan lagu kebangsaan, menghormati lambang-lambang negara, dan lain-lain, diramalkan akan bubar pada tahun 2030. Tapi sayangnya Prabowo tidak mencantumkan atau menyertakan dari mana data tersebut direferensikan. Di saat pemerintah selalu menyajikan informasi di tengah masyarakat (baik melalui media massa maupun dalam komunikasi politik langsung pemerintah kepada rakyat) dengan data-data yang melimpah, justru Prabowo (sebagai oposan) justru tampil dengan minus data referensi.

Bak petir di siang bolong, Prabowo ingin menciptakan sebuah kejutan yang "mengehentak" tetapi tidak menemukan "gaung"-nya karena tidak menyertakan data sama sekali dari mana dasarnya. Hal ini justru menyebabkan banyak kalangan mempertanyakan apa yang menjadi penyataan Prabowo tersebut. Foucault menyebut hal seperti ini sebagai the limit and forms of memory, yaitu keterbatasan dan bentuk-bentuk memori atau teks memori seperti buku harian, catatan risalah, dan lain-lain. Keterbetasan ini 
tentu saja membuat tingkat kepercayaan wacana yang coba Prabowo wacanakan menjadi rendah.

\section{Analisis Archaeology of Knowledge}

Archaelogy of knowledge (arkeologi pengetahuan) merupakan salah satu yang khas dari analisis discourse Foucault. Yang dimaksud archaeology of knowledge adalah seperangkat metodologi yang dapat digunakan untuk mempelajari bagaimana retorika atau pernyataan-pernyataan yang disampaikan dapat dipelajari dan dipahami dalam kaitannya dengan kekuasaan (power) dan pengetahuan (knowledge).

Foucault melihat bahwa semua bahanbahan (manifest) discourse didasarkan secara tersembunyi pada apa yang diucapkan (already said), yaitu tidak hanya frasa yang telah diucapkan atau teks yang telah tertulis, tetapi tidak pernah diucapkan (never said), yang berkaitan (incorporated) dengan discourse, suara yang sunyi seperti nafas, tulisan yang hanya merupakan bagian dari pendandanya sendiri. Dengan kata lain, archaelogy of knowledge menyediakan seperangkat metodologi bagi peneliti untuk melihat dan memahami discourse yang ada dengan melihat bahasa-bahasa yang tampak dan tidak tampak, ujaran-ujaran yang dikatakan dan ujaran-ujaran yang tersembunyi yang tidak pernah disampaikan, termasuk tulisan-tulisan yang bahkan tidak jelas dan tidak dapat dibaca sekalipun (Ida, 2014: 122).

Pidato singkat Prabowo bisa dibagi kedalam tiga bagian penting, yaitu: bagian pembukaan yang berupa ramalan bubarnya Indonesia, bagian isi berupa penguasaan asset yang timpang, dan penutup berupa kesimpulan Probowo tentang perilaku elit Indonesia. Pada bagian pembukaan, Probowo secara kontradiktif menceritakan tentang ramalan bubarnya Indonesia pada tahun 2030.

“ Kita masih upacara, kita masih menyanyikan lagu kebangsaan, kita masih pakai lambang-lambang negara, gambargambar pendiri bangsa masih ada di sini, tetapi di negara lain mereka sudah bikin kajian-kajian, di mana Republik Indonesia sudah dinyatakan tidak ada lagi tahun 2030."

Kalimat tersebut harus dipahami dalam konteks yang lebih spesifik, terutama berkaitan dengan siapa Prabowo yang mengatakan hal tersebut. Harus dipahami bahwa Prabowo hingga saat ini adalah satusatunya penantang kuat Jokowi dalam Pilpres 2019 mendatang. Dari sisi "ketokohan", Prabowo merupakan tokoh kaliber nasional yang sangat diakui ketokohannya. Selain itu, Prabowo juga merupakan Ketua Umum Partai Gerindra. Semenjak kalah tipis dalam Pilpres 2014, Prabowo memposisikan diri dan partainya sebagai oposisi. Posisi ini menempatkan dirinya sebagai lambang oposan yang populer.

Tidak mengherankan bila "apa yang keluar dari mulut Prabowo" akan dimaknai sebagai suara pihak oposisi. Apa yang diucapkan selalu dianggap dan dipersepsikan "selalu menyerang" pemerintah (Jokowi) meskipun tidak diungkapkan secara langsung. Bahkan lebih sering tidak menyebut Presiden atau nama Jokowi.

Seperti dalam kalimat diatas, Prabowo secara tidak langsung menganggap apa yang dilakukan oleh pemerintah selama ini tidak menunjukkan tanda-tanda perbaikan hidup masyarakat. Sebagai sebuah bangsa, Indonesia terjebak pada rutinitas upacara-upacara kenegaraan, yang melibatkan lambanglambang negara dan lagi kebangsaan. Prabowo mengkritik kurangnya focus pemerintah Jokowi pada aspek kesejahteraan rakyat sehingga muncul ramalan bahwa Indonesia akan bubar 2030.

Keberadaan Prabowo sebagai tokoh sentral oposisi berkorelasi dengan kuasa yang dimilikinya. Kekuasaan di sini tidak dimaknai secara sempit dalam ruang lingkup tertentu atau menjadi milik seseorang atau lembaga resmi kenegaraan atau pemerintahan. Tetapi lebih dilihat sebagai relasi antara subyek dan peran dari lembaga-lembaga yang menjalankan fungsi tertentu dalam masyarakat. Peranan Prabowo sebagai tokoh oposisi yang menyuarakan suara masyarakat yang tidak sejalan dengan pemerintah menunjukkan arti kekuasaan Prabowo sendiri.

Melalui kalimat pertama ini, Prabowo mewacanakan bahwa dirinya mempercayai bahwa bila tidak ada perubahan pemerintahan (pesiden diganti), indonesia akan bubar di tahun 2030. Meskipun tanpa data atau dokumen yang otentik dan sesuai dengan pernyataanya, wacana tersebut tetap digulirkan karena Prabowo tidak percaya dengan pemerintahan saat ini.

Wacana yang dihembuskan ini secara perlahan akan menciptakan kategorisasi- 
kategorisasi, siapa yang setuju dengan pandangannya dan siapa yang setuju dengan langkah-langkah ataupun kebijakan pemerintahan Jokowi saat ini. Ini akan memicu gejolak (pro dan kontra) dan membuat pemerintah "kalang kabut" sehingga mendorong pemerintah untuk memadamkan gejolak tersebut karena menurut Foucault, dalam wacana seperti ini, yang disentuh kuaa bukan fisik melainkan jiwa, pikiran, kesadaran dan kehendak individu.

Pada bagian isi, Prabowo mengemasnya ke dalam lima kalimat. Prabowo mengungkapkan cerita tentang kepemilikan asset (tanah) di Indonesia yang mayoritas dikuasai para elit ekonomi yang jumlahnya hanya sekitar 1 persen dari seluruh penduduk Indonesia. Ia juga berbicara tentanf perilaku elit Bangsa Indonesia yang mempunyai kecenderungan negatif dan mengabaikan bangsanya sendiri dan lebih suka "memanjakan" bangsa lain.

\section{"Bung! \\ Mereka ramalkan kita ini bubar, elit kita ini merasa bahwa 80 persen tanah seluruh negara dikuasai 1 persen rakyat kita, nggak apa-apa. \\ Bahwa hampir seluruh aset dikuasai 1 persen, nggak apa-apa. \\ Bahwa sebagian besar kekayaan kita diambil ke luar negeri tidak tinggal di Indonesia, tidak apa-apa. \\ Ini yang merusak bangsa kita, saudara-saudara sekalian!"'}

Secara jelas terlihat bahwa Prabowo mengkritik elit politik Indonesia yang tidak lain adalah pemerintahan Jokowi. Meskipun tidak menyebut nama Jokowi atau jabatan presiden, sangat terlihat bahwa yang ia maksud elit adalah pemerintahan Jokowi. Karena yang biasa mengatur persoalan pertanahan dan pengolahan sumber daya alam, hanyalah pemerintah. Maka sekali lagi yang dikritik dalam kalimat ini adalah pemerintahan Jokowi.

Dalam pidato tersebut, Prabowo sebenarnya juga mencoba mengungkap siapa yang terlibat dalam perusakan bangsa ini. Secara khusus ia menyebut kata "elit" yang mengacu pada sekelompok tertentu masyarakat yang mempunyai kedudukan dan akses khusus terhadap kekuasaan di negeri ini. "Elit" berinsinuansi sekelompok penguasa, walaupun belum tentu si penguasa tertinggi.
Ini menunjukkan bahwa Prabowo sedang "menunjuk" yang berkuasa di negeri ini. Meskipun sebenarnya Prabowo juga termasuk kelompok "elit", tetapi seakan dia melepaskan dirinya dari kelompok "elit" tersebut. Ia mencoba melepakan identitas dirinya dan menyatu dengan kelompok yang sedang diajak bicara yaitu massa.

Meskipun singkat, pidato Prabowo tersebut juga mengungkapkan cara yang dilakukan para elit, yaitu membiarkan penguasaan sebagian asset bangsa oleh segelintir orang dan membiarkan kekayaan alam kita mengalir ke luar negeri. Para elit disebut membiarkan sekelompok minoritas yang jumalhanya hanya sekitar satu persen menguasai asset bangsa. Dengan mudah kita dapat menyimpulkan bahwa yang dimaksud Prabowo adalah pengusaha etnis Tionghoa yang memang karena kekayaannya bisa menguasai ekonomi nasional. Bagi Prabowo ini jelas mengganggu dan harus dihentikan. Tetapi menurutnya, para elit pemerintahan kita membiarkannya. Penguasa cenderung tidak peduli dengan rakyatnya dan hanya peduli kepada sekelompok kecil masyarkat (pengusaha) yang mengungkan penguasa.

Demikian halnya dengan pembiaran kekayaan alam kita mengalir ke luar negeri. Dengan jelas juga mengkritik pemerintah yang mempermudah perizinan penanaman modal asing (PMA) untuk beberapa sector industry seperti pertambangan, perikanan, dan lain-lain. Tapi Prabowo lupa bahwa, pada saat itu sedang ada upaya dari pemerintah untuk membawa kembali Freeport ke tanah air yaitu membeli saham mayoritasnya. Sebelumnya presiden Jokowi juga telah membubarkan perusahaan Petral yang ternyata hanya menjadi ladang subur bagi koruptor kita di Singapura.

Pada bagian penutup atau akhir dari pidatonya, Prabowo mencoba membuat kesimpulan dengan cara menggunakan kalimat:

\section{"Semakin pintar, semakin tinggi kedudukan, semakin curang! Semakin culas! Semakin maling!}

Tidak enak kita bicara, tapi sudah tidak ada waktu untuk kita pura-pura lagi."

Dari kalimat tersebut, Prabowo ingin mengatakan bahwa ada kecenderungan manusia Indonesia semakin mereka pintar, semakin tinggi kedudukan kita di masyarakat, 
semakin besar peluang kita untuk melakukan kecurangan atau bertindak curang. Semakin besar peluang kita untuk melakukan tindakantindakan culas. Dan membawa kita pada kecenderungan untuk mencuri yang bukan milik kita. Dalam konteks kritikan Prabowo, maka tindakan-tindakan curang, culas dan maling ini tidak bisa dilepaskan dari konteks penguasaan asset tanah air. Curang, culas dan maling ini adalah tindakan-tindakan yang dilakukan para elit politik nasional yang menurutnya "menggadaikan" kepentingan nasional kepada asing dan memperkaya diri mereka sendiri

Kritik dan wacana ini sebenarnya bukan merupakan hal yang baru, beberapa pihak pernah menyampaikan kritikan terhadap perilaku pejabat yang cenderung korup dan mementingkan diri sendiri. Tetapi kritik mereka tidak lantas diakhiri dengan kesimpulan bahwa 2030 Indonesia akan runtuh. Pada umumnya pengkritik masih percaya bahwa Indonesia akan tetap berdiri tegak.

Peneliti melihat, melalui dengan membangun wacana bahwa Indonesia akan bubar tahun 2030, Prabowo ingin mencoba sebuah cara baru dalam menyampaikan kritik terhadap pemerintah. Kalau diperhatikan, pidato yang dilakukan oleh Prabowo secara singkat tersebut sangatlah penuh strategi. Ia menyampaikan point of interest nya secara langsung, mengungkapkan bentuk penindasan dan cara-cara yang dilakukan oleh elit dalam menindas rakyat, menunjukkan bagaimana ketidakpedulian elit terhadap hal setsebut dan pada akhirnya menggarisbawahi siapa yang diuntungkan dan siapa yang dirugikan.

Pada akhir pidatonya, Prabowo menjelaskan secara tegas yang diuntungkan adalah para elit yang adalah curang, culas dan maling ini. Sedangkan yang dirugikan adalah seluruh rakyat Indonesia, karena mereka akan terpecah belah dan bahkan Indonesia akan bubar.

Maka Prabowo memutuskan untuk selalu terbuka dan tidak menutup-nutupi fakta. Dengan mengatakan "Tidak enak kita bicara, tapi sudah tidak ada waktu untuk kita purapura lagi", Prabowo menghendaki para elit penguasa untuk terbuka dan melihat masalah negara dengan lebih jernih dan transparan.Jangan ada dalih-dalih tertentu dibalik kebijakan-kebijakan yang diambil oleh pemerintah. Kepentingan yang utama adalah rakyat, maka pertimbangan dari seluruh keibajakn negara hendaknya mempertimbangkan kebutuhan masyarakat sebagai warga negara.

\section{Analisis Formasi Diskursif}

Dalam formasi diskursif (discursive formation), peneliti melihat bagaimana kejadian atau peristiwa (event) dan discourse yang dihasilkan. Formasi diskursif bisa berupa discourse-discourse yang terbentuk dan beredar dalam masyarakat tentang suatu hal.

Dalam konteks Prabowo sebagai oposisi, wacana-wacana yang dihadirkan oleh kelompok oposisi memang sangat beragam. Wacana ini sudah dikembangkan sejak Pilpres 2014 dan hingga kini masih menjadi wacana atau setidaknya isu hangat yang selalu "digaungkan". Mulai dari isu Jokowi PKI, Keturunan Tionghoa, pemerintahan yang lemah, pekerja proyek tidak cocok jadi presiden, musuh muslim, kriminalisasi ulama, Pro asing dan terutama aseng, menghamburkan uang untuk infrastruktur, kemiskinan semakin banyak, mencari pekerjaan semakin susah, serbuan tenaga kerja asing, berbagai macam hoaks, dan lain-lain.

Semua itu pada dasarnya merupakan discourse atau wacana yang dibangun dan diedarkan oleh pihak-pihak opisisi dengan tujuan untuk menggoyang pemerintah atau minimal mengurangi kepercayaan public kepada pemerintah. Berbagai wacana digunakan untuk mempengaruhi pengetahuan masyarakat tentang pemerintah yang ada. Kemampuan oposisi dalam membangun dan mengedarkan berbagai wacana tersebut sebenarnya menunjukkan bahwa oposisi sebenarnya mempunyai kekuasaan yang cukup besar, karena dalam formasi diskursif, pembangunan dan distribusi discourse selalu dipengaruhi oleh kekuasaan, ideology, dan pengetahuan tertentu. Dalam pemahaman peneliti, kelompok oposisi sebenarnya mempunyai resourches yang luar biasa besar.

Melalui pidato ini, Prabowo sedang membangun dan menyebarkan wacana bahwa pemerintah Jokowi tidak peduli terhadap asset negara sehingga Indonesia akan runtuh sebagaimana ramalan beberapa orang. Ketidakpedulian asset ini juga berarti ketidakpedulian pemerintah terhadap kepentingan rakyatnya. Pemerintah saat ini diisi oleh orang-orang yang curang, culas dan maling sehingga punya potensi membuat negara menjadi bangkrut. 
Namun wacana ini terasa aneh karena sebenarnya menepikan wacana lainnya atau mendiamkan wacana lainnya. paling tidak terlihat dari bagaimana Prabowo sengaja tidak menyebut langsung pemerintah yang berkuasa sekarang. Penyebutan elit adalah bentuk pengaburan siapa secara spesifik yang bertanggungajwab terhadap hal tersebut. Dalam perspektif wacana Foucault ini termasuk dalam unsur-unsur yang di absen dan sengaja didiamkan untuk tujuan-tujuan tertentu.

Unsur-unsur lain yang didiamkan antara lain: siapa sebenarnya yang bertanggungjawab terhadap kekayaan alam Indonesia, siapa 1 persen yang dimaksudkan Prabowo? Kalau memang orang Indonesia dan tidak melanggar Undang-Undang, kenapa harus dipermasalahkan? Juga tidak jelaskan rakyat yang mana yang menjadi korban. Selain itu, sebenarnya dimana posisi Prabowo sendiri? Dia elit atau rakyat biasa? Faktnya dia adalah seorang ketua partai yang mempunyai 73 perwakilan di DPR. Artinya, Prabowo bukan rakyat biasa dan bagian dari elit itu sendiri.

Di luar wacana yang digulirkan oleh Prabowo, pemerintah sendiri melalui Presiden Jokowi bukannya tidak membangun wacana. Jokowi sendiri dari awal terpilih, membangun wacana sebagai pemerintahan yang bersih, revolusi mental, membangun dari pinggiran, wujudkan nawacita, mengedepankan kerja dengan slogan: "kerja, kerja dan kerja", pemerintahan yang merakyat, dan lain-lain. Semua wacana tersebut dibangun dan disebarkan oleh pemerintahan Jokowi hingga saat ini.

Pertanyaan menariknya adalah apakah semua wacana tersebut nyata? Banyak ahli menyatakan tidak semua terlaksanan dengan baik. Pemerintahan yang bersih, revolusi mental, dan mewujudkan nawacita merupakan contoh-contoh wacana yang sekedar wacana belaka dan tidak ada wujud nyatanya. Tetapi tidak sedikit yang memang dijalankan dan berhasil dijalankan oleh Jokowi beserta jajarannya. Misalnya wacana membangun dari pinggiran. Jokowi merupakan presiden RI yang berhasil membangun infrastruktur di seluruh pelosok tanah air dan daerah-daeah perbatasan dipercantik.

Demikian juga dengan slogan "kerja, kerja dan kerja". Hampir setiap hari media massa nasional menampilkan presiden Jokowi satu hari ke kota $\mathrm{A}$, sorenya ke kota $\mathrm{B}$, besok kota $\mathrm{C}$ dan seterusnya, yang menggambarkan Jokowi tidak perah berhenti memikirkan rakyatnya. Ini sekaligus juga membangun wacana kedekatan Jokowi dengan rakyat di Indonesia.

Keberhasilan beberapa wacana Jokowi ini, rupanya membuat pihak oposisi "panasdingin" sehingga perlu membuat wacana lain untuk memenangkan pengetahuan rakyat tentang pemerintahan yang ada sekarang. Maka serangkaian wacana digelontorkan oleh para oposisi, termasuk Prabowo sebagai "pentolan oposisi", untuk membuat masyarakat atau rakyat Indonesia tidak terlalu percaya dengan kinerja Jokowi. Dalam jangka pendek, ini diyakini akan bisa menghapus ingatan pendek masyarakat akan keberhasilan pemerintah dan mengingatkan rakyat akan janji-janji Jokowi ketika pertama kali terpilih menjadi Presiden.

Dalam jangka panjang, masyarakat menjadi selalu pesimis dengan pemerintahan Jokowi sehingga pada saatnya digerakkan untuk membuat keputusan (baca: pemilu), bisa diarahkan untuk memilih sosok di luar Jokowi, salah satunya Prabowo sendiri. Dalam rangkaian kontestasi pilpres 2019, wacana yang digelontorkan oleh Prabowo menjadi salah satu upaya pertarungan wacana demi mendapatkan memori pengetahuan masyarakat tentang pemerintahan Jokowi.

Pemilihan kata "elit" dan "satu persen" penguasa asset negara, ingin mengingatkan masyarakat bahwa terjadi ketidakadilan yang merugikan eluruh rakyat Indonesia. Sebagai bagian dari rakyat, Prabowo mencoba mengingatkan kembali bahwa mereka berhak mendapatkan pemimpin yang lebih pro rakyat dan peduli kepada kesejahteraan rakyat.

Tetapi memang, seperti telah ditemukan dalam analisis arsip, wacana ini terlalu lemah dan cenderung mempunyai kecacatan sejak disebarluaskan. Ketiadaan bahan acuan dan sumber data yang rasional, membuat wacana ini seperti layu sebelum berkembang. Acuan yang hanya berdasarkan sebuah cerita fiksi, justru membuat Prabowo menjadi "bulan-bulanan" para politisi pro pemerintah dan para netisen. Akibatnya, justru para politisi oposan sibuk menyelamatkan "muka" Prabowo di setiap kesempatan. 


\section{HASIL DAN PEMBAHASAN}

Wacana yang diangkat oleh Prabowo dalam kritik nya terhadap pemerintahan Jokowi memang mengalami anti klimaks. Wacana tersebut layu sebelum berkembang karena memiliki kelemahan dari sisi kerarsipan. Namun demikian, sebenarnya apa yang di sampaikan Prabowo tersebut masih bisa menjadi sebuah bola liar dalam hirukpikuk perpolitikan nasional kita dan punya peluang untuk mengguncang, tidak sekedar hoak belaka. Tentu dengan syarat Prabowo mampu menghadirkan data-data yang lebih sahih dan rasional.

Apa yang diungkap Prabowo sebetulnya membantu masyarakat untuk mengidentifikasi ada beberapa kekhawatiran atau ketakutan bahwa kepentingan masyarakat banyak (Indonesia) akan dikesampingkan. Sumber daya alam Indonesia akan menjadi ajang eksploitasi oleh perusahaan-perusahaan multinasional. Bagi peneliti, kekhawatiran ini sangat masuk akal karena (kalau data yang digunakan Prabowo benar) dengan pemberian prioritas pada para pengusaha dan dukungan yang besar pemerintah terhadap pembangunan selama ini, peluang untuk terjadinya eksploitasi sangat besar.

Isu bubarnya NKRI telah menjadi wacana dalam politik nasional kita beberapa minggu terakhir. Dalam hal ini, Prabowo telah berhasil mengkonstruk realitas subyektif dalam realitas sosial masyarakat untuk kepentingan dirinya. Melalui power yang dimiliknya, Prabowo menanamkan pemahaman pesimisme dalam benak masyarakat bahwa negara bisa saja gagal dan pemerintahan yang ada sekarang pun berpeluang juga untuk gagal, maka perlu diganti segera.

Namun dengan minus data yang memadai, wacana eksploitasi ini menjadi terpinggirkan atau terdiamkan sehingga justru memperlemah wacana yang dikembangkan Prabowo. Kelemahan ini membuat peluang memperbesar "daya ledak" wacana ini menjadi kecil. Bahkan dalam beberapa kesempatan, Prabowo mengakui bahwa ia mendapatkan data dari sebuah novel atau karya fiksi.

Dari sisi strategi dan teknik pewacanaan, Prabowo tampak sekali berpihak kepada rakyat sebagai korban dari ketidakmampuan Jokowi mengelola negara. Pidato ini setidaknya membuka beberapa ketidakberesan sosial yang saat ini masih terjadi di Indonesia, antara lain: penguasaan asset negara yang tidak adil; perilaku elit politik yang masih saja "curang", "culas", "maling"; dan keterbukaan pemerintah.

Dalam pidato ini, memang ditemukan beberapa unsur yang hilang atau sengaja didiamkan, tetapi justru mempunyai makna yang sangat penting. Ada beberapa unsur penting yang didiamkan Prabowo, antara lain: pertama, siapa sebenarnya yang bertanggungjawab terhadap kekayaan alam Indonesia, siapa 1 persen yang dimaksudkan Prabowo? Ini penting untuk memberikan gambaran bahwa kritikan Prabowo tersebut masuk akal dan logis. Kalau tidak dijelaskan sangat mudah untuk discounter. Kalau ternyata yang 1 persen tersebut adalah memang orang Indonesia dan tidak melanggar Undang-Undang, kenapa harus dipermasalahkan? Kedua, Prabowo tidak menjelaskan rakyat yang mana yang menjadi korban. Kalau rakyat yang dimaksud adalah anggota partai Gerindra sendiri, maka sebenarnya tidak perlu wacana tersebut mereka pasti akan menolak apapun kebijakan Jokowi karena mereka oposan. Harusnya Prabowo "memaknai" rakyat yang di luar sana (di luar partai) sehingga potensi merubah pandangan masyarakat terhadap Jokowi lebih besar.

Ketiga, sebenarnya dimana posisi Prabowo sendiri? Dia elit atau rakyat biasa? Hingga saat ini, faktnya dia adalah seorang ketua partai yang mempunyai 73 perwakilan di DPR. Artinya, Prabowo bukan rakyat biasa dan bagian dari elit itu sendiri. Persoalan pemilihan kata atau diksi menjadi masalah sendiri buat Prabowo. Pemilihan diksi yang salah dalah sebuah stuktur justru bisa menjadi "kuburuan untuk dirinya sendiri". 


\section{SIMPULAN}

Dari penelitian yang dilakukan, peneliti mengambil kesimpulan bahwa dibalik pidato Prabowo Subiyanto tentang bubarnya NKRI di tahun 2030, terdapat pertarungan wacana yang melibatkan para oposan Jokowi untuk merebut pengetahuan dan memori masyarakat terhadap jalannya pemerintahan Jokowi. Hanya saja, Prabowo melakukan kesalahan dengan melupakan keberadaan datadata pendukung yang menguatkan kritik dan wacana yang dikembangkan.Banyaknya unsur yang terpinggirkan atau terdiamkan juga turut memperlemah wacana yang dikembangkan Prabowo. Akumulasi dari kedua haltersebut membuat "daya ledak" wacana ini menjadi hilang.

Meskipun antiklimaks, sebenarnya apa yang diungkap Prabowo sebetulnya cukup membantu masyarakat untuk mengidentifikasi tentang adanya beberapa kekhawatiran atau ketakutan bahwa kepentingan masyarakat banyak (Indonesia) akan dikesampingkan. Sumber daya alam Indonesia akan menjadi ajang eksploitasi oleh perusahaan-perusahaan multinasional. Wacana bubarnya NKRI telah berhasil menjadi wacana dalam politik nasional. Dalam hal ini, Prabowo telah berhasil mengkonstruk realitas subyektif dalam realitas sosial masyarakat untuk kepentingan dirinya. Melalui power yang dimiliknya, Prabowo menanamkan pemahaman pesimistis dalam benak masyarakat bahwa negara bisa saja gagal dan pemerintahan yang ada sekarang pun berpeluang juga untuk gagal, maka perlu diganti segera.

\section{DAFTAR PUSTAKA}

Arifin, Anwar, Prof. Dr., 2011, Komunikasi Politik, Filsafat, Paradigma, Teori, Tujuan, strategi dan Komunikasi Politik Indonesia, Yogyakart: Graha Ilmu

Blummer, Herbert, 1969, Symbolic Interactionism: Perspective and Method, Englewood Cliffs, N.J.: Prentice-Hall

Denzin, Norman K. \& Lincoln, Yvonna S., Handbook Of Qualitative Research, California: SAGE Publications.

Dominick, Joseph R., 2009, The Dynamics of Mass Communication, Media in The
Digital Age, tenth edition, New York: McGraw-Hill

Firmansyah, Prof. Ph.D., 2011, Mengelola Partai Politik, Komukasi dan Posisioning Ideologi Politik Di Era Demokrasi, Jakarta: Pustaka Obor Indonesia

Foucault, Michel, 1972, The Archeology of Knowledge \& the Discourse of Language, New York: Pantheon Books

Foucault, Michel, 1997, Ethics: Subjectivity and Truth, Vol. 1. Diedit oleh Paul Rabinow (New York Press)

Giddens, Anthony 1984, The Constitution of Society: Outline of the Theory of Structuration, Cambridge: Polity Press

Haryatmoko, 2016, Critical Discourse Analysis, Landasan Teori, Metodologi dan Penerapan, Jakarta: Rajagrafika Persada

Henink, Hutter, \& Bailey, 2011, Qualitative Research Methods, London: SAGE Publications.

Hendrikus, Dori Wuwur, 1991, Retorika Terampil Berpidato, Berdiskusi, Berargumentasi, Bernegosiasi, Yogyakarta: Kanisius.

Ida, Ranchma, 2014, Metode Penelitian Studi Media dan Kajian Budaya, Jakarta: Prenada Media Group.

Kellner, Douglas, 1995, Media Culture: Culture Studies, Identity and politics Between the Momdern And the Postmodern, London: Routledge

Littlejohn, Stephen W \& Karen A. Foss.2009. Teori Komunikasi, edisi 9. Jakarta: Salemba Humanika

Magnis-Suseno, Franz, 2000, Pemikiran Karl Marx, Dari Sosialisme Utopis ke Perselisihan Revisionisme, Jakarta: Gramedia

Marvin, C \& Meyer, P, 2009, The Future of News, The Future of Journalism, The Press,

Poerwandari, E. Kristi, 2007, Pendekatan Kualitatif untuk Penelitian Perilaku Manusia, Jakarta: LPSP3 Universitas Indonesia

Poespowardojo, Soerjanto.TM \& Seran, Alexander, 2016, Diskursus TeoriTeori Kritis, Kritik Atas Kapitalisme Klasik, Modern, dan Kontemporer, Jakarta: Kompas

Ritzer, George \& Goodman, Douglas J., 2004, Sociological Theory: Karl Marx and 
Varieties of Ne-Marxian Theory, New York: McGraw-Hill

Ritzer, George, 2005, Teori Sosial Posmodern, Yogyakarta: Kreasi Wacana

Sumarlam (Ed). 2008. Teori dan Praktek Analisis Wacana. Surakarta: Pustaka Cakra

Sutrisno, Mudji and Putranto, Hendar. 2005. Teori-Teori Kebudayaan. Yogyakarta: Kanisius

Widyarsono, A., 1999, Hubungan Kuasa Dan Pengetahuan Menurut Foucault, Majalah Filsafat Driyarkara Tahun XXII No 4 Hal 4-2. 